\title{
Reforming the EU VAT system to support the transition to a low-carbon and resource efficient economy
}

This is a draft chapter. The final version is available in:

Larry Kreiser ... (eds.): Carbon pricing -

Design, Experiences and Issues. - Cheltenham : Elgar, 2015, pp. 111-126. DOI:

10.4337/9781785360237

The material cannot be used for any other purpose without further permission of the publisher, and is for private use only. 
Bettina Bahn-Walkowiak, $a^{*}$

Henning Wilts, a

\section{Reforming the EU VAT system to support the transition to a low-carbon and resource efficient economy}

a Wuppertal Institute for Climate, Environment, Energy, Germany

* Corresponding author:

Bettina Bahn-Walkowiak

Wuppertal Institute for Climate, Environment, Energy

Döppersberg 19

D-42103 Wuppertal

Germany

E-mail: bettina.bahn-walkowiak@wupperinst.org

Phone: +49 202-2492 276

Fax: +49 202-2492 138

This is the author's version of a work that was accepted for publication. Changes resulting from the publishing process, such as editing, corrections and structural formatting, may not be reflected in this document. Changes may have been made to this work since it was submitted for publication. A definitive version was subsequently published in the book cited above. 


\section{Introduction}

This paper discusses the question of ecologically differentiated value added taxes (VAT) as a tool to overcome tax-related cognitive barriers by connecting to an existing tax system. This is elaborated along several aspects: (a) The role indirect of consumption taxes for the economy, (b) the legal issues of the VAT system, (c) the EU harmonization efforts in this context, (d) the distributional implications of value added taxes.

Following this, the paper develops a proposal for a VAT reform (e). To this end, it looks at potential and existing differentiations between sectors, products and services, and product and service groups and turns to those consumption areas that are widely identified as particularly resource and carbon intensive and sets out how a harmonization of the overall system and an ecological differentiation in single consumption areas could be brought together. Potential impacts and effects are briefly discussed (f) and some conclusions are drawn (g). The subject addressed in the paper is relevant from a policy perspective but mainly descriptive: It does not use innovative qualitative and quantitative tools.

\section{The Value Added Tax (VAT) System in the European Union}

Despite efforts to expand the portfolio of environmentally oriented market-based instruments (EEA 2005), recently renewed by the 'getting the prices right and reorienting the burden of taxation' objective of the EU Roadmap (EC 2011a, p. 10), the use of economic incentives such as taxes is reluctant. The share of environmental taxes in the total tax revenue of the EU (approximately 6 per cent in 2011) seems too low for substantial progress towards a low-carbon and resource efficient economy. According to the EU Roadmap, all Member States have to 'review their fiscal policies and instruments with a view to supporting resource efficiency more effectively, and in this context reflect on incentives to support consumer choices and producer action in favour of resource efficiency' by 2013. Although the public rarely pays attention to economic instruments as strongly as to the value added tax (VAT) and the VAT system affects the households' consumption decisions due to its price impacts (Albrecht 2006), it is rarely discussed as an environmental instrument as such (Sterner \& Coria 2011; Kosonen \& Nicodème 2009) or as element of an environmental tax reform (Ekins \& Speck 2011). VAT is levied in all European countries and, apart from the US, in all OECD countries. 'The spread of VAT has been the most important development in taxation over the last half century. Limited to less than ten countries in the late 60s, it has now been implemented by more than 150 countries' (OECD 2012, p. 44).

\subsection{The Role of Indirect Consumption Taxes for the Economy}

Indirect consumption taxes ${ }^{1}$ are one of the main sources of income in developed countries. In OECD countries, the share of the indirect consumption taxes in the

\footnotetext{
1 Indirect taxes include the value added tax and excise taxes (energy tax, tobacco tax, electricity tax, taxes on alcoholic beverages or alcopops, and so on). Direct taxes refer to personal income and property; they include corporate taxes.
} 
overall government revenues is approximately 34 per cent. On average, about two thirds come from the VAT; one third comes from other consumption taxes such as excise duties on mineral oil, tobacco or alcoholic beverages (OECD 2012).

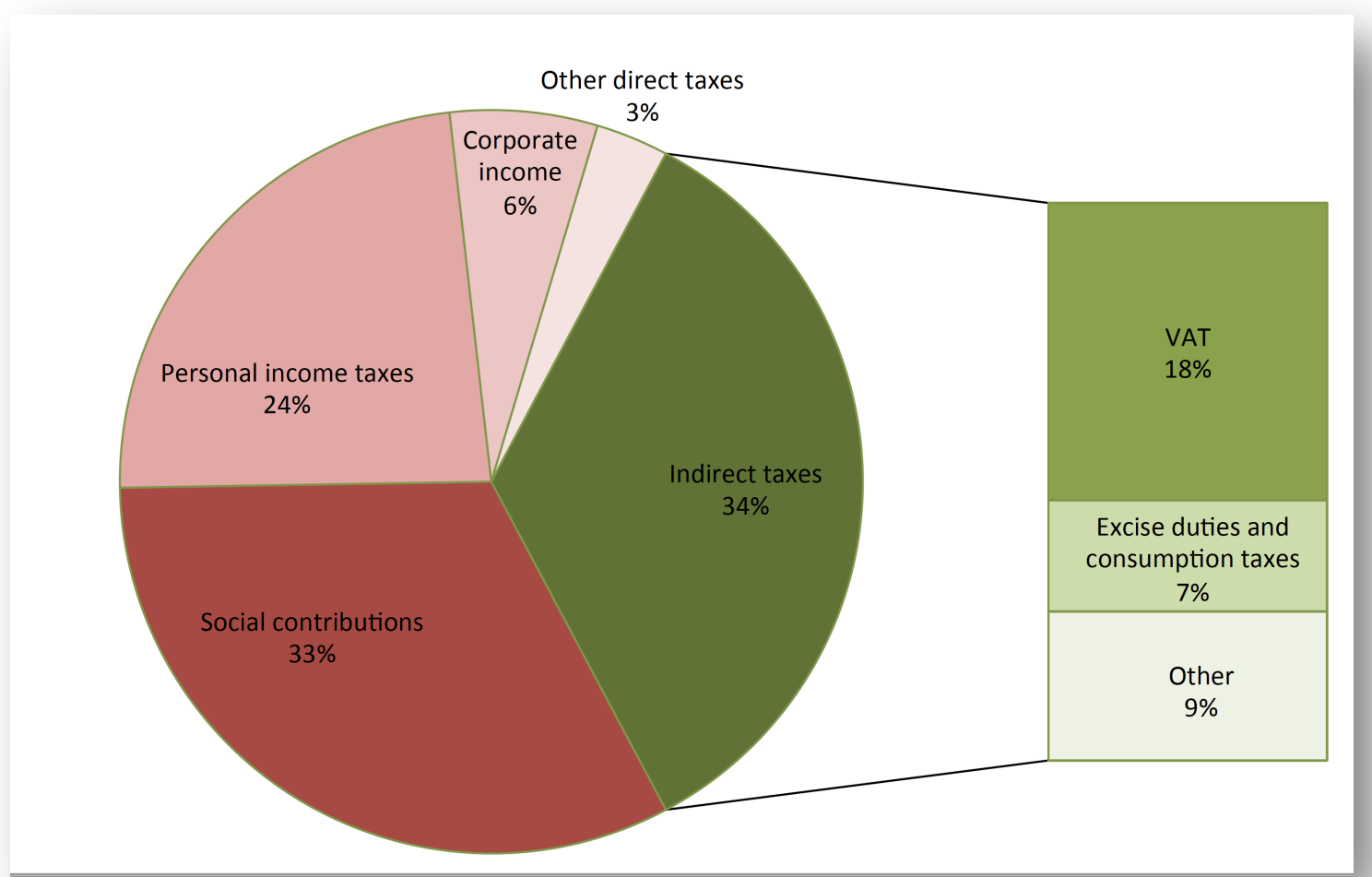

Source: Own compilation on the basis of Eurostat data.

Figure 1Direct and indirect taxes, EU 2011, as percentage of total tax revenue

The VAT is a transfer tax triggered by transactions between economic actors. All upstream services are entitled to the deduction of the input tax, provided they have been charged in commercial transactions before. The cumulative tax burden is usually passed on to the consumers all along the value chain where it is an excise tax charged on end users.

The EU VAT Directive 2006/112/EC allows flexibility in formulating the national VAT system but stipulates that a tax of at least 15 per cent have to be collected. Standard rates vary from 15 per cent (Luxembourg) to 27 per cent (Hungary). Two reduced rates of at least 5 per cent are allowed but currently restricted to 21 categories of product and services, mainly on the basis of social motives (for example, foodstuffs, water, pharmaceuticals, medical equipment, books, and so on). Reduced rates vary from 5 per cent (for example, the UK) to 15 per cent (Czech Republic) and additional super reduced rates (for example, France, Ireland, Italy, Luxembourg, Spain) are in the range of 2-4 per cent. Further zero rates/exemptions for public services are common (in other words, they are taxable for VAT but the rate is zero) (EC 2014). 
There is no European-wide consensual rationale for standard rates, exemptions and zero rates. Hence, VAT rates are widely inconsistent due to different cultures and traditions (EC 2014; Eurostat 2013; OECD 2012).

\subsection{The Legal Context of the EU VAT System and the Harmonization Efforts}

The first European VAT directives were adopted in 1967. Under Article 93 EC a modification of the VAT Directive requires unanimity voting of the European Council, for example, for the introduction of additional products and services subject to a reduced rate.

There are currently 21 categories of products and services for which the EU directive allows reduced VAT rates (IFS 2011), essentially corresponding to those also known as merit goods. ${ }^{2}$ Tax neutrality is considered to be an important principle in the EU, stating that regardless the length of the value chain like-products should have the same tax burden (Lohse 1999). The term 'like-products', however, does not refer to the manufacturing processes or the material input of the goods and calls for interpretation. The extended Ecodesign Directive acknowledges 'very different degrees of environmental impact despite similar functional performances' (EC 2009a, para. 3) pointing to the inhomogeneity of products. In the absence of effective resource efficiency labels, this provision could serve as a suitable starting point for the introduction of ecologically oriented VAT rates. 3

A European Commission proposal for a Council Directive amending the VAT Directive of 2006 as regards reduced VAT rates first brought up the question of 'a reduced rate to energy saving materials and to other environmentally beneficial products or services' and 'of eliminating reduced rates for environmentally prejudicial products such as pesticides' (EC 2008, p. 2f.; EC 2007). In the follow up, the EU commissioned several studies on the VAT system and its economic effects (for example, CEP 2009; IVM 2008).

Some studies conclude that an ecological VAT differentiation would only result in minor or no consumption shifts (CE 2007, 2008; CEP 2009) in the realm of energy or energy efficient products and services and emphasized state revenues losses and market distortions. Other studies expect positive interactions of the impacts on environment and innovation (for example, IVM 2008; De Camillis \& Goralczyk 2013).

A Green Paper then called for 'maximizing revenue collection' and initiated a consultation process with stakeholders and Member States (MS) (EC 2010; EC 2011b; 2011c). Estimations comparing the actual and theoretical VAT revenues conclude

\footnotetext{
2 Food, water, pharmaceuticals, medical equipment, children's car seats, passenger transport, books, newspapers, periodicals, cultural services and amusement and sport events, TV, writers/composers, social housing, renovation and repairing of private dwellings, cleaning in private households, agricultural inputs, hotel accommodation, restaurant and catering services, sporting facilities, social services, services of undertakers and cremation, medical and dental care, domestic waste collection and street cleaning, minor repairing (bicycles, shoes, clothing), domestic care services, hairdressing.

3 European law exclusively backs the implementation of reduced VAT rates in national legal frameworks within the given framework of the Articles 98 and 106 and Annexes III and IV (EC 2006).
} 
that revenues could almost be twice as high (Eurostat 2013) when a harmonized single rate was and evasion could be avoided. Simultaneously, there have been significant movements in most MS. Only five out of 28 countries have left their tax rates completely unchanged in the last decade (Eurostat 2014). Eighteen countries have particularly modified the reduced rates and eight countries have even introduced additional reduced rates. Despite strong interest in harmonizing the tax rates by abolishing reduced rates and exemptions and avoiding evasion in order to raise the tax revenues, a near-term convergence of the different frameworks and an implementation of a single rate seem rather unlikely.

\subsection{The distributional implications of VAT changes}

Conflicts particularly arise in the context of reduced VAT rates (Albrecht 2006; ZEW 2004; Peffekoven 2009; UBA 2010). The distributional effects of the VATs are - especially in the public debate - highly sensitive. It is argued that the VAT is not based on the financial capacity of the taxpayers, different than the income tax. Households with a low income would therefore bear a proportionately heavier burden through the VAT than households with a high income (ZEW 2004). While the regression effect is largely undisputed, estimations on the extent differ greatly (Kosonen 2012). In a study on the distributional effects of a potential German VAT reform, a regressive but rather moderate effect was revealed: The relative burden of the net income by the VAT for the bottom tenth of the households is about 10 per cent, whereas the relative burden for the upper tenth of the households is about 6 per cent (Ochmann \& al. 2012).

While one position holds on to the exemptions for food and rents motivated by distribution policy, another position argues for a full elimination of VAT reductions and notes that an abolition of reduced rates would have only a slight regressive effect (ZEW 2004). In addition, life cycle effects can become relevant in terms of distributional effects, for example in the case of household appliances and mobility (Ochmann et al. 2012; De Camillis \& Goralczyk 2013). A tax reduction or exemption is often rather a disguised industry subsidy than a social policy tool (Experian 2009). Sometimes, resource- and carbon-intensive sectors and product groups such as the agricultural and food system benefit from a two-level subsidization, in other words, the sector receives on-budget subsidies at the beginning of the value chain as direct financial support and a preferential treatment through VAT reductions as off-budget subsidies at the end of the value chain (IEEP 2012). These points contribute to the fact that VAT rates are a hotly contested terrain, both as a direct incentive as well as an indirect subsidy.

\section{Potential scope of differentiations in the VAT system and reform proposals}

Current VAT differentiations and exemptions follow social, educational, cultural or health reasons. There is sectoral differentiation, differentiation between products and services, and product and service groups. Although differentiations of tax rates 
can lead to market distortions and macro-economic disadvantages (EC 2011c), the state distinguishes between eligible and less eligible purposes, such as tax benefits for foundations and other non-profit organizations.

The simple idea behind ecologically differentiated VAT rates is to give subsidies or tax exemptions ('bonus') for environmentally friendly products and/or additional fees/higher taxes ('penalty') for the purchase of less green alternatives (BIO IS 2012). The comparative advantage of tax preferences is in providing support for positive externalities generating addition social benefits (Greene \& Braathen 2014). The following will outline the potential scope of differentiations and give some examples (Bleischwitz 2012; Bahn-Walkowiak et al. 2010).

\subsection{Differentiations between Sectors}

In 2009, the European Parliament voted for a sectoral differentiation: the introduction of reduced VAT rates for locally supplied labour-intensive services (EC 1999; EC $2009 \mathrm{~b}$ ) affecting various sectors, inter alia, the hotel and catering industry, parts of skilled craft and trades, such as renovation and repair of private dwellings and services of barbers, shoemakers and bicycle craft. The services have to be labourintensive, largely provided to end users, be mainly local, not create distortions of competition, and there must be a close link between the reduction of prices resulting from the VAT rate reduction and a foreseeable increase in demand and employment. The clause specifically refers to industries that are partly competing with private labour-intensive services and illegal employment (EC 2009b).

\section{Standard VAT rates for resource and carbon-intensive food}

The example of the food sector demonstrates that sectoral tax benefits hinder the access to resource efficiency potentials. The sector is not only one of the sectors with the strongest environmental impacts (EEA 2013; UNEP 2010), it also entails an enormous amount of wastage. At the same time, the raw materials are comparatively cheap and partially subsidized by the governments (for example, milk and dairy products). Since food is considered as merit goods by legislation they are, regardless of the production methods and the associated consequences for the environment and health favoured by tax cuts.

Westhoek et al. (2011) indicate that the European meat consumption is twice as high and the consumption of dairy products is three times higher than the world average. An analysis of meat and dairy products revealed that the sector - while constituting 6 per cent of the economic value of the total final consumption - contributes 24 per cent of the environmental impacts in EU-27 (JRC 2008). As a full abolition of the reduced rates on food would very likely run into major opposition of businesses and consumer organizations, a normal VAT rate on the most resource and carbonintensive food could thus gain acceptance. These include mainly meat, dairy and frozen products (EEA 2012). Calculations of IVM (2008) showed that an increase in VAT for conventional meat and dairy products to the standard rate in all MS would result in a consumption decrease of 2-7 per cent for meat and 2-5 per cent for dairy 
products. Taking into account possible shifts in organic products and conventional foods, this would result in a $\mathrm{CO}_{2}$ reduction of 12-21 million tonnes of $\mathrm{CO}_{2}$ per year (IVM 2008; see Table 1). Most MS currently use one or more of the reduced tax rates. Only Bulgaria, Denmark, Estonia, Lithuania, Romania and Slovakia raise standard rates of at least 20 per cent on food. Alternatively, it could be a useful measure to support the organically produced meat and dairy products with a VAT reduction.

\subsection{Differentiations among Functionally Identical Products}

Differentiation can also be made within a group of functionally identical products. Then criteria verifying resource-efficient or carbon-intensive products are needed. Ideally, life cycle analyses regarding resource and carbon intensity and environmental impacts would be available for all products (as suggested by De Camillis \& Goralczyk 2013). The Ecodesign Directive for energy-using equipment does not cover all products and only takes a limited number of indicators for energy efficient devices into account (EC 2005). Nevertheless, the use of such complex eligibility and differentiation criteria would require specialized staff that is likely to be more expensive and less effective (Greene \& Braathen 2014). Alternatively, a variety of eco-labels exist and could be employed for VAT differentiations. They would be favourably dynamic (for example, Top Runner lists) 4 because products considered to be resourceefficient at their market introduction will probably be average performers after a few years. This also calls for regular monitoring.

\section{Reduced VAT rates on energy- and resource-efficient household appliances}

In 2010, the residential sector accounted for almost 30 per cent of total final electricity consumption, thus playing an important role for efficiency programmes and policies. Only the industry sector had a larger share (36 per cent); the services sector 29 per cent and transport 2 per cent (JRC 2012). Up to 20 per cent of the electricity consumption of private households is caused by cooling and freezing of food alone (Barthel et al. 2005).

Although the average energy consumption of household per year drops already by 1-5 per cent (IVM 2008), the proportion of A++ appliances of refrigerators and freezers sold in 2007 were only 8 per cent and 11 per cent respectively. Due to the fact that aspirations rise and life cycles and innovation cycles are dramatically shortening, electrical appliances are among the top sectors in terms of sales and earning potential. Although the penetration rate is almost 100 per cent for refrigerators, 4.3 million units are still sold each year in Germany (Barthel et al. 2005). The 'Retailers' Environmental Action Plan' (ERRT 2012) calls for advancing innovation for resourcesaving and energy efficient appliances.

\footnotetext{
4 The Eco Top Ten rating system created for Germany shows up-to-date market surveys for ecological products in various product fields, such as living, mobility, textiles, food, home appliances and consumer electronics, information and communication technologies and investments (www.ecotopten.de). Other countries use such approaches too.
} 
Household appliances are subject to a standard rate all over Europe and the sector is characterized by a strong competition; a nearly 100 per cent transfer of the tax reduction to the consumers can be expected. Little data exists concerning the price elasticity of demand, especially for large household appliances. However, there have been positive experiences in some EU countries with direct government subsidies for energy-efficient products. In the Netherlands, a programme has led to an increase in sales of about 15 per cent and a market share of 15-40 per cent. In Italy, there is a rebate on income tax, in Spain a discount sale for old products (IVM 2008). It is proposed to allow for reduced VAT rates on labelled energy and material efficient and low carbon products and services in the household appliances sector.

\subsection{Differentiations between Product/Service Groups}

The current VAT system already differs between product and service groups. In the EU, especially the domestic transport is treated very differently. Rates range from o per cent (UK) up to 27 per cent (Hungary) (EC 2014).

The intra-community and international air transport is not VAT charged by any European country, whereas a number of countries, including Belgium, Greece, Netherlands and Spain apply a reduced VAT rate for long-distance passenger transports by rail; Germany and Austria even use a standard rate. As regards domestic public transport, 14 European MS collect reduced or zero tax rates. Eight countries use a standard rate of more than 15 per cent. Rail transport is strongly competing with road transport, also concerning freight. This fact is supported by a large share of EU subsidies directed toward road investments (Bahn-Walkowiak et al. 2012).

\section{Harmonization of the system regarding sustainable transport modes}

In the current design of the VAT system in Germany, for example, public transport is favoured by 7 per cent, long-distance rail transport is subject to the standard rate of 19 per cent, while flight transport is fully exempted. Despite air ticket charges that have been introduced in Germany, France, England and the Netherlands (Greenpeace 2008; FÖS 2008) VAT exemptions for international flights are still classified as harmful to the environment (UBA 2010; Rave 2008) - a disguised transport subsidy promoting an unsustainable means of transport. The European Parliament (EP) consequently notices market distortions and an uneven playing field in the transport 'since all modes of transport are competing for the same crossborder transport services' (EP 2011, p. 5). In order to promote sustainable transport in times of growing inter-community transport, the relevant mechanisms should systematically be refocused on urban and regional public transport for passengers and an intermodal infrastructure shifting of freight from road to rail. VAT adaptation could be one element and harmonization of tax rates should be fostered

\section{Potential impacts and effects}

An instrument can be described as efficient, when a given environmental objective cannot be achieved at lower costs; only less ambitious environmental targets may be reached at given costs. In this sense, an instrument can be considered suitable if it 
can bring about a change in the desired direction (CEP 2009). Regarding the effectiveness of VAT increases and reductions, there is little doubt that they have an impact on the demand due to subsequent price changes (CE 2007). An important factor for the market effect is the intensity of competition of the goods involved: In highly competitive markets a 100 per cent pass-through of reductions to consumers is more likely than in monopolistic markets. The rate of price adjustment is also dependent on the capital intensity of production. When an expansion of production capacities is associated with high costs, a price reduction is passed on to consumers much more slowly due to longer depreciation periods (CE 2008). It is also possible that VAT increases result in price increases due to overcompensation or reductions that are not fully passed through. 5 Those effects are more pronounced with increases than decreases (asymmetric cross-price elasticity).

Ecologically differentiated VAT rates, as proposed in the previous sections, could contribute to the overcoming of barriers for resource efficient or less carbon intensive consumption decisions. The abolition of VAT reductions for products associated with strong negative externalities would lead to a reduction of the external costs to be borne by society and tax-cuts for environmentally friendly innovations and products would lead to positive externalities. Table 1 gives an overview on estimated demand changes and related GHG emissions reduction potentials based on previous VAT changes. ${ }^{6}$

5 An increase of the VAT by 10 per cent for magazines in Italy, for example, led to an increase of prices by 14 per cent. The reduction of the VAT on books in Sweden by 19 per cent led to a lowering of prices by 12 per cent (CE 2007).

6 The table summarizes results from comprehensive modelling exercises of the Institute for Environmental Studies in the year 2008 which are cited here for illustrating the potential order of magnitudes. 
Table 1 Ex ante estimation of demand shifts and GHG reduction potentials in million tonnes by specific VAT rate changes in selected product groups

\begin{tabular}{|c|c|c|}
\hline Product category & Demand increases/ decreases & $\begin{array}{l}\text { Estimated GHG } \\
\text { emissions reduc- } \\
\text { tion in EU* }\end{array}$ \\
\hline $\begin{array}{l}\text { Energy efficient central heating boilers } \\
\text { (Case study: Application of reduced rates) }\end{array}$ & $\begin{array}{r}2004-2014: \\
+43 \%-75 \%\end{array}$ & $\begin{array}{r}18 \text { million tonnes; } \\
\text { approx. } 5 \%\end{array}$ \\
\hline $\begin{array}{l}\text { Energy efficient refrigerators, fridge-freezers, washing } \\
\text { machines }(\mathbf{A}+/ \mathbf{A}++) \\
\text { (Case study: Application of reduced rates) }\end{array}$ & up to $+15 \%$ & $\begin{array}{r}3 \text { million tonnes; } \\
\text { approx. } 5 \%\end{array}$ \\
\hline $\begin{array}{l}\text { Thermal insulation materials } \\
\text { (Case study: Application of reduced rates) }\end{array}$ & $+3.0-12.2 \%$ & $\begin{array}{r}23-36 \text { million } \\
\text { tonnes }\end{array}$ \\
\hline $\begin{array}{l}\text { Electricity } \\
\text { (Case study: Application of the individual standard rates } \\
\text { in those } 10 \mathrm{EU} \text { countries which use the reduced rates) }\end{array}$ & $-3-4 \%$ & $\begin{array}{r}20 \text { million tonnes } \\
(\text { in 2005) }\end{array}$ \\
\hline $\begin{array}{l}\text { Electricity } \\
\text { (Case study: Application of reduced rates for electricity } \\
\text { from renewable energy) }\end{array}$ & $+2.5 \%$ & 2.8 millions tonnes \\
\hline $\begin{array}{l}\text { Meat and dairy products } \\
\text { (Case study: Application of standard rates with a possible } \\
\text { exemption for organic products) }\end{array}$ & $\begin{array}{r}\text { Meat: }-2-7 \% \\
\text { Dairy products: }-2-5 \% \\
\text { Organic meat/ dairy products: } \\
+6-16 \%\end{array}$ & $\begin{array}{r}12-21 \text { million } \\
\text { tonnes }\end{array}$ \\
\hline
\end{tabular}

*Note: in $\mathrm{Mt} \mathrm{CO}_{2}$-eq. /a

Source: IVM 2008.

A quantitative analysis of the economic effects of a resource efficiency strategy for Germany simulated modified VAT rates for long-distance passenger transport services by rail (introduction of reduced rates) and air (abolition of exemption/introduction of standard rates). The case study revealed that the price signals would induce demand shifts and thus reduce energy consumption and $\mathrm{CO}_{2}$ emissions. As regards material consumption, the results showed interactions between a decline of air travel contributing to reductions in oil consumption and increases in the consumption of coal and gas for the electricity generation due to an increasing rail travel (Distelkamp et al. 2010).

The signalling effect of decreasing or increasing sales triggered by a tax reduction or an abolition of exemptions of a product or service is sometimes critically assessed in comparison with direct incentives (Kosonen \& Nicodème 2009) but should give in- 
centives to producers to expand resource efficiency potentials of their products and services. A dynamic design of the tax categories allowing for an exchange between higher and lower tax classes could give an additional impetus for companies to provide information on the resource intensity of their products when they are rewarded with a lower VAT rate in case of compliance. It can also lead to a sectoral benchmark serving as an opportunity to break established path dependencies and to strengthen the focus on successful first-movers. A coupling of differentiated VAT rates to a benchmarking system could be an interesting perspective.

VAT exemptions or advantages for resource-efficient products are thus used to reduce price barriers for final consumers. A VAT reduction for a commodity such as a refrigerator or a national rail ticket could result in significant price reductions and further contribute to social benefits. A certain tax rate could become an environmental selection criterion for end users. It may be argued that labels can do the job more effectively which is true. In view of the existing label overload and the high level of public attention to VAT changes in general, it can however be assumed that changes of VAT rates for specific products and services can contribute to the reduction of information asymmetries.

Finally, an increase in demand for 'green' products may lead to innovative learning curve effects. If a breakthrough from a niche market to mass production can be achieved through the reduction of the VAT rate economies of scale lead to further dynamic price and innovation effects. Compared with the administrative costs for the banning of single polluting products (for example, the light bulbs ban due to the EU eco-design directive) tax incentives can be a smart solution that could meet more consent and allow for better adaption of the economy.

\section{Concluding remarks}

From an economic perspective, taxes are usually second-best policies due to their inherent impreciseness (Söderholm 2011). From an environmental perspective, taxes are a step towards reflecting the full external and social costs of resource use. In general, price increases by implementation of taxes should create incentives to reduce the use of the product or service (depending on the range of the rate) or substitute it by an alternative product or service. Like all subsidies also tax preferences should ideally be established for a defined time period, and their costs and benefits should be assessed at appropriate intervals (Greene \& Braathen 2014).

At present, differentiations are made within the VAT system predominantly for social but not for environmental reasons and without considering the social distribution of ecological positive and negative externalities. Aside from that, a very substantial feature of a tax is the ability to influence behaviour if one wants to modify patterns of consumption. A proposal of the European Parliament 'calls for a Green VAT strategy to be devised, centred on reduced rates for energy-efficient and environmentally friendly products and services, counterbalancing unfair competition which results from externalities not reflected in the price of a good or service' (EP 2011, p. 6). The consumption tax rates provide a good basis to make resource consumption and en- 
vironmental effects visible. The possibilities for differentiation of consumption taxes should therefore be expanded to include ecological options by expanding the Annex III of the VAT Directive (EC 2006) and the harmonization efforts should focus on adjusting and correcting distorting and environmentally harmful reduced rates. This will nevertheless require clear and transparent eligibility criteria in order to minimize additional administrative efforts. 


\section{References}

Albrecht J. (2006), 'The use of consumption taxes to re-launch green tax reforms', International Review of Law and Economics 26 (1), 88-103. DOI:10.1016/j.irle.2006.05.007.

Bahn-Walkowiak B., Usubiaga A. and Schepelmann P. (2012), 'EU structural and cohesion policy and sustainable development', in Kreiser L. et al. (eds), Carbon Pricing, Growth And The Environment - Critical Issues in Environmental Taxation, Vol. XI, Cheltenham, UK and Northampton, MA, USA: Edward Elgar Publishing, 17-32.

Bahn-Walkowiak B., Wilts H., Bleischwitz R. and Sanden J. (2010), Differenzierte Mehrwertsteuersätze zur Förderung eines ressourceneffizienteren Konsums, Ressourceneffizienz Paper 3.6, Project Material Efficiency and Resource Conservation (MaRess), Wuppertal Institute for Climate, Environment, Energy.

Barthel C., Irrek W., Thomas S. and Hohmeyer O. (2005), 'Energieeffiziente Kühl- und Gefriergeräte.

Beschreibung eines möglichen Förderprogramms eines Energieeffizienz-Fonds', Wuppertal Institute/University Flensburg, http://wupperinst.org/uploads/tx_wupperinst/EnEff-Fonds_Anhang2_Programm8.pdf, accessed at 15 January 2015.

BIO IS (2012), Policies to Encourage Sustainable Consumption, Paris: Bio Intelligence Service.

Bleischwitz R. (2012), 'Towards a resource policy - unleashing productivity dynamics and balancing international distortions', Miner Econ 24 (2-3), 135-144, DOI: 10.1007/s13563-011-0114-5.

CE (2007), Study on Reduced VAT Applied to Goods and Services in the Member States of the European Union, Copenhagen: Copenhagen Economics.

CE (2008), Reduced VAT for Environmentally Friendly Products, Copenhagen: Copenhagen Economics/DG TAXUD.

CEP (2009), Ermäßigte Mehrwertsteuersätze als Instrument der Umweltpolitik in der EU, Freiburg, Centrum für Europäische Politik. http://www.foes.de/pdf/CEP-Studie\%20Mehrwertsteuer.pdf, accessed 15 January 2015.

De Camillis C. and Goralczyk M. (2013), 'Towards stronger measures for sustainable consumption and production policies: Proposal of a new fiscal framework based on a life cycle approach', International Journal of Life Cycle Assessment 18, 263-272, DOI 10.1007/s11367-012-0460-5.

Distelkamp M., Meyer B. and Meyer M. (2010), Quantitative und qualitative Analyse der ökonomischen Effekte einer forcierten Ressourceneffizienzstrategie, Ressourceneffizienz Paper 5.6, Project Material Efficiency and Resource Conservation (MaRess), Wuppertal Institute for Climate, Environment, Energy.

EC (1999), Council Directive 1999/85/EC of 22 October 1999 amending Directive 77/388/EEC as regards the possibility of applying on an experiment basis a reduced VAT rate on labour-intensive services, OJ L 277/34.

EC (2005), Council Directive 2005/32/EC of 6 July 2005 establishing a framework for the setting of ecodesign requirements for energy-using products and amending Council Directive 92/42/EEC and Directives 96/57/EC and 2000/55/EC of the European Parliament and of the Council, OJ L 191/29.

EC (2006), Council Directive 20o6/112/EC of 28 November 2006 on the common system of value added tax, OJ $\mathrm{L} 347 / 1$.

EC (2007), Communication from the Commission to the European Parliament and the Council on VAT rates other than standard VAT rates, 5 July 2007, COM(2007) 380.

EC (2008), Proposal for a Council Directive amending Directive 2006/112/EC as regards reduced rates of value added tax, 7 July 2008, COM(2008) 428.

EC (2009a), Council Directive 2009/125/EC of 21 October 2009 establishing a framework for the setting of ecodesign requirements for energy-related products (recast), OJ L 285/10.

EC (2009b), Council Directive 2009/47/EC of 5 May 2009 amending Directive 2006/112/EC as regards reduced rates of value added tax, OJ L 116/18.

EC (2010), Green Paper on the future of VAT - Towards a simpler, more robust and efficient VAT system, 1 October 2010, COM(2010) 695. 
EC (2011a), Roadmap to a Resource Efficient Europe, COM(2011) 571, Brussels, European Commission.

EC (2011b), Summary Report of the Outcome of the Public Consultation on the Green Paper on the Future of VAT - Towards a Simpler, More Robust and Efficient VAT System (1 December 2010 to 31 May 2011), Brussels, European Commission.

EC (2011c), Communication from the Commission to the European Parliament, the Council and the European Economic and Social Committee on the future of VAT - Towards a simpler, more robust and efficient VAT system tailored to the single market, 6 December 2011, $\operatorname{COM(2011)~} 851$.

EC (2014), VAT Rates Applied in the Member States of the European Union, Brussels, European Commission.

EEA (2005), Market-based instruments for environmental policy in Europe - EEA Technical Report No. 8/2005, Copenhagen, European Environment Agency.

EEA (2012), Consumption and the environment - 2012 update; the European environment - state and outlook 2010, Copenhagen, European Environment Agency.

EEA (2013), Environmental pressures from European consumption and production - EEA Technical Report No 2/2013, Copenhagen, European Environment Agency.

Ekins P. and Speck S. (eds) (2011), Environmental Tax Reform (ETR) - A Policy for Green Growth, Oxford: Oxford University Press.

EP (2011), Report on the future of VAT, Plenary sitting, A7-0318/2011, Brussels, European Parliament, Committee on Economic and Monetary Affairs.

ERRT (2012), REAP - Retailers' Environmental Action Programme - revised 14 June 2012, Brussels, European Retail Round Table, http://ec.europa.eu/environment/industry/retail/pdf/reap_tor.pdf, accessed 15 January 2015 .

Eurostat/European Commission (2013), Taxation trends in the European Union, Data for the EU Member States, Iceland and Norway, 2013 edition, Luxembourg: EC.

Eurostat/European Commission (2014), Taxation trends in the European Union, Data for the EU Member States, Iceland and Norway, 2014 edition, Luxembourg: EC.

Experian (2009), The Opportunities and Costs of Cutting VAT - The Effects of Selected Reductions in the rate of VAT on the Labour Element of Housing Repair Maintenance and Improvement, London, Cut the VAT campaign, www.fmb.org.uk/EasySiteWeb/GatewayLink.aspx?alId=161361, accessed 15 January 2015.

FÖS (2008), Umweltschädliche Subventionen und Steuervergünstigungen des Bundes, Hamburg, Greenpeace.

Greene J. and Braathen N.A. (2014), Tax Preferences for Environmental Goals - Use, Limitations and Preferred Practices, OECD Environment Working Papers, No. 71, OECD Publishing, http://dx.doi.org/10.1787/5jxwrr4hkd6l-en, accessed 8 January 2015.

Greenpeace (2008), Umweltschädliche Subventionen und Steuervergünstigungen des Bundes, Hamburg.

IEEP (2012), Study supporting the phasing out of environmentally harmful subsidies - Final Report for the European Commission, DG Environment, Brussels, Institute for European Environmental Policy (IEEP), Institute for Environmental Studies - Vrije Universiteit (IVM), Ecologic Institute, VITO.

IFS (2011), A retrospective evaluation of elements of the EU VAT system - Final Report for the European Commission, TAXUD, London, Institute for Fiscal Studies.

IVM (2008), The use of differential VAT rates to promote changes in consumption and innovation - Final Report, Commissioned by European Commission, DG Environment, Amsterdam, Vrije Universiteit, Institute for Environmental Studies.

JRC (2008), Environmental Improvement Potentials of Meat and Dairy Products, Seville, Joint Research Centre Institute for Prospective Technological Studies.

JRC (2012), Energy Efficiency Status Report 2012, Ispra, Joint Research Centre. 
Kosonen K. and Nicodème G. (2009), The Role of Fiscal Instruments in Environmental Policy, Taxation Papers, Working Paper No. 19, Luxembourg.

Kosonen K. (2012), 'Regressivity of environmental taxation: Myth or reality?' in Milne J.E. and Skou-Andersen M. (eds), Handbook of Research on Environmental Taxation, Cheltenham, UK, and Northampton, MA, USA: Edward Elgar Publishing, 161-174.

Lohse C.W. (1999), Die Zuordnung im Mehrwertsteuerrecht. Bd. 13 von Schriften zum Umsatzsteuerrecht, Berlin, Otto Schmidt.

Ochmann R., Bach S. and Beznoska M. (2012), The Retrospective Evaluation of Elements of the VAT System The Case of Germany, Research project on behalf of the European Commission, TAXUD, Berlin, Deutsches Institut für Wirtschaftsforschung.

OECD (2012), Consumption Tax Trends 2012: VAT/GST and Excise Rates, Trends and Administration Issues, Paris: OECD, DOI: $10.1787 / \mathrm{ctt}-2012-\mathrm{en}$.

Peffekoven R. (2009), 'Mehrwertsteuererhöhung: Keine nachhaltige Konsolidierung', Wirtschaftsdienst 7, 426427.

Rave T. (2008), 'Subsidy impact assessment and subsidy monitoring: opportunities to advance the reform of environmentally harmful subsidies in Germany', in Chalifour N. et al. (eds), Critical Issues in Environmental Taxation: International and Comparative Perspectives, Volume V, Oxford: Oxford University Press, 621-648.

Söderholm, P. (2011), 'Taxing virgin natural resources: Lessons from aggregates taxation in Europe', Resources, Conservation and Recycling, 55, 911-922, DOI:10.1016/j.resconrec.2011.05.011.

Sterner T. and Coria J. (2011), Policy Instruments for Environmental and Natural Resource Management, 2nd edn, New York, London: RFF Press.

UBA (2010), Umweltschädliche Subventionen in Deutschland, Dessau, Federal Environment Agency.

UNEP (2010), Assessing the Environmental Impacts of Consumption and Production - Priority Products and Materials, A Report of the Working Group on the Environmental Impacts of Products and Materials to the International Panel for Sustainable Resource Management, Nairobi, United Nations Environment Programme (UNEP).

Westhoek H.J. et al. (2011), 'The protein puzzle: The consumption and production of meat, dairy and fish in the European Union', European Journal of Food Research and Review, 1 (3), 123-144.

ZEW (2004), Allokative und distributive Effekte einer Abschaffung des ermäßigten Umsatzsteuersatzes; Commissioned by Federal Ministry of Finances, Mannheim, Centre for European Economic Research. 